\title{
Keanekaragaman Kepiting Biola (Uca spp.) di Ekosistem Mangrove Desa Pasir, Kabupaten Mempawah Kalimantan Barat
}

\author{
Niqki Actuti ${ }^{1 *}$, Apriansyah ${ }^{1}$, Syarif Irwan Nurdiansyah ${ }^{1}$ \\ 1 Program studi Ilmu Kelautan, FMIPA, Universitas Tanjunpura, Pontianak- \\ Indonesia \\ *Correspondence email: Niqki Actuti \\ $\bowtie$ niqkiactuti@gmail.com
}

\author{
Received:17 December 2018- Accepted: 08 February 2019 \\ Published: 28 February 2019 @ Author(s) 2019. This article is open access
}

\begin{abstract}
Ekosistem mangrove merupakan sumber daya pesisir memiliki habitat untuk berbagai jenis biota salah satunya kepiting biola. Kepiting biola (Uca spp.) adalah salah satu biota khas mangrove berperan penting dalam menjaga keseimbangan rantai makanan dalam ekosistem mangrove. Tujuan dari penelitian ini untuk Mengetahui keanekaragaman jenis $U c a$ spp. yang berada di Desa Pasir. Penelitian ini menggunakan metode purposive, di buat 4 plot pengamatan. Hasil penelitian menunjukan bahwa terdapat 3 spesies $U c a$ yaitu spesies dari Uca forcipata, $U$. dussuimeiri dan $U$. rosea, dengan keanekaragaman dan keseragaman rendah serta dominansi tinggi. Dominansi tertinggi terdapat pada plot 4 yang didominansi oleh $U$. forcipata, sedangkan 3 plot lainnya tergolong sedang. Faktor yang mempengaruhi tinggi rendahnya indeks keanekaragaman, keseragaman dan dominansi yaitu kondisi lingkungan meliputi $\mathrm{pH}$ tanah, kondisi substrat, pasang surut dan vegetasi mangrove serta pengaruh aktivitas manusia.
\end{abstract}

Keywords: Keanekaragaman, kepiting biola (Uca spp.), mangrove

\section{Pendahuluan}

Hutan mangrove merupakan ekosistem yang kompleks terdiri atas flora dan fauna daerah pantai sekaligus habitat didaratan dan di laut, biasanya dipengaruhi oleh pasang air laut (Indriyanto, 2010). Ekosistem mangrove berperan sebagai habitat atau tempat tinggal, sebagai tempat beraktivitas, reproduksi dan mencari makan bagi berbagai jenis biota. Ekosistem mangrove juga menjadi tempat perlindungan biota dari predator dan cekaman lingkungan (pasang surut dan salinitas tinggi) (Kustanti, 2011). Biota akuatik adalah biota yang hidup kawasan mangrove dikelompokan atas dua tipe yaitu organisme yang hidup di kolom air (berbagai jenis udang dan ikan) dan organisme yang hidup menempati substrat, terutama untuk jenis kerang dan berbagai jenis kepiting (Nybakken 1992). Desa Pasir berada di Kecamatan Mempawah Hilir memiliki ekosistem mangrove yang menjadi tempat wisata yang dikenal sebagai Mempawah Mangrove Park (MMP). Kawasan ekowisata tersebut merupakan bentuk keberhasilan masyarakat serta instansi sekitar dalam mengelola sumber daya pesisir (Khairudin, 2015).

Kepiting biola (Uca spp.) merupakan salah satu biota khas mangrove. 
kepitingbiola berperan penting dalam menjaga keseimbangan rantai makanan dan siklus nitrogen dalam ekosistem mangrove (Natania, 2017). Saat ini ekosistem mangrove semakin terdesak oleh kencenderungan meningkatnya kebutuhan untuk menggunakan lahan, untuk memenuhi kebutuhan manusia sehingga mengancam kelestarian di dalamnya (Muniarti, 2010).

Penelitian tentang keanekaragaman kepiting biola sebelumnya pernah dilakukan oleh beberapa ahli. Suprayogi et al,. (2012) menemukan 3 spesies kepiting biola di ekosistem mangrove yaitu $U$. forcipata, $U$. dususuimeiri dan $U$. rosea. Penelitian Muniarti, (2010) menemukan 8 spesies kepiting biola, diantaranya $U$. rosea dan $U$. dussuimeiri. Serta Hamidah et al,. (2014) ditemukanya 3 spesies dengan yang paling banyak Uca jantan di banding betina.

Aktivitas wisata di kawasan ekosistem mangrove MMP (Mempawah Mangrove Park) dapat beresiko mengganggu kehidupan Uca spp. yang hidup di dalamnya. Mengingat seberapa pentingnya biota akuatik khususnya biota yang hidup di kawasan mangrove maka perlu dilakukan penelitian terkait keanekaragaman dan kurangnya data mengenai keanekaragaman jenis kepiting biola di Desa Pasir, khususnya MMP (Mempawah Mangrove Park), menjadikan penelitian mengenai "Keanakeragaman kepiting biola (Uca spp.) di ekosistem mangrove Desa Pasir Kabupaten Mempawah Kalimatan Barat" penting untuk dilakukan.

\section{Metode}

\subsection{Waktu dan tempat}

Pengambilan data telah dilaksanakan pada tanggal 14 sampai 17 Agustus 2017 di Desa Pasir, khususnya MMP (Kabupaten mempawah Kalimantan Barat (Gambar 1).

\subsection{Metode Penelitian}

Penelitian ini dilakukan dengan observasi secara langsung di lokasi penelitian. Sampling dilakukan pada 4 lokasi yang ditentukan secara purposive berdasarkan skema atau jalur MMP yang berada di Desa Pasir (Mempawah Mangrove Park) yaitu area paling depan (Plot 1), area tengah (Plot 2 ), area tengah belakang (Plot t3) dan area paling ujung (Plot 4). Pada setiap plot dibuat kuadran berukuran $1 \times 1 \mathrm{~m}$ menggunakan tali rapia (Gambar 2).

\subsection{Pengambilan Sampel}

Pengambilan data kepiting biola dilakukan pada pagi hari ketika air surut. Sampel kepiting biola diambil atau digali menggunakan sekop kecil dengan panjang 40 $\mathrm{cm}$ dan kedalaman $30 \mathrm{~cm}$. Sampel kepiting biola yang telah diperoleh dihitung dan kemudian diawetkan dengan menggunakan alkohol 75\% (Gita, 2015) lalu dimasukkan

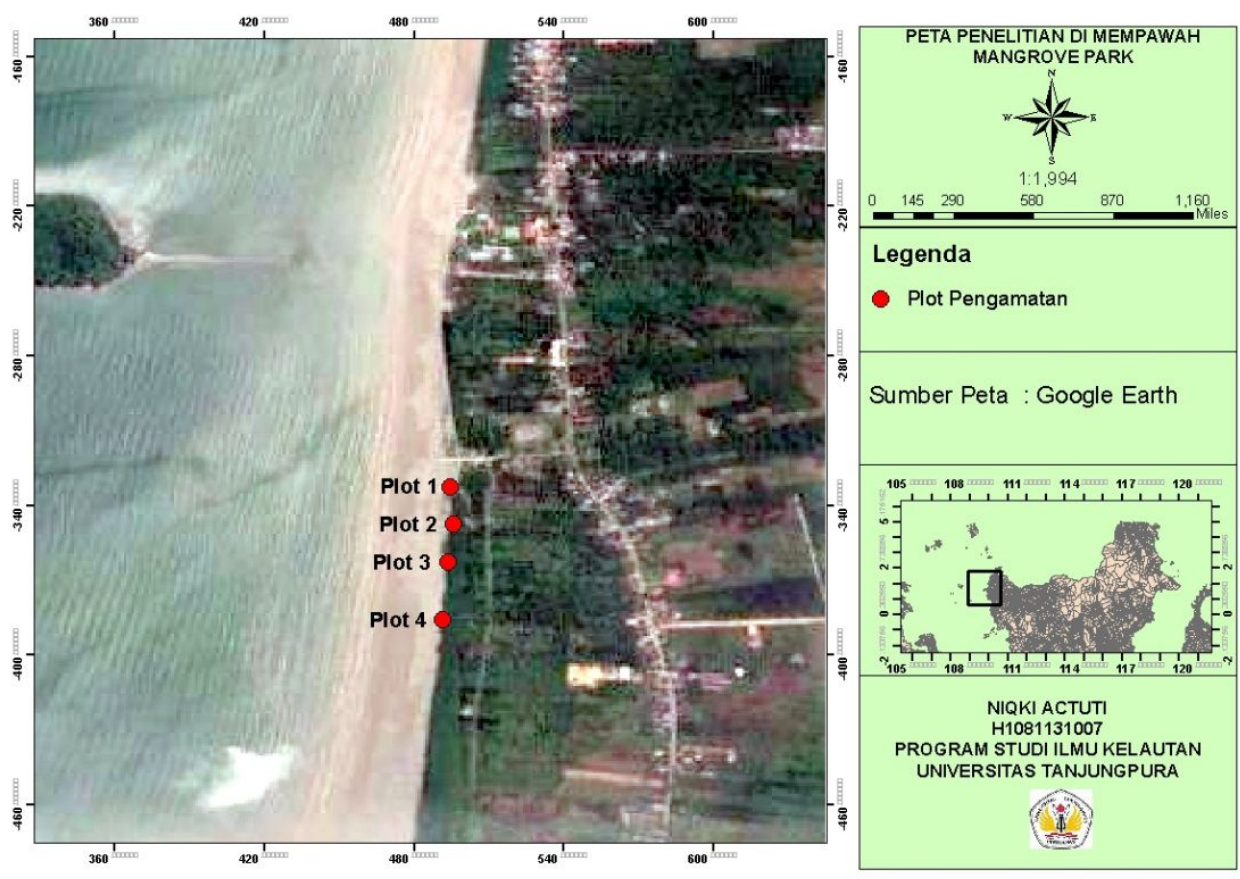

Gambar 1. Lokasi pengambilan sampel dilakukan pada 4 titik 


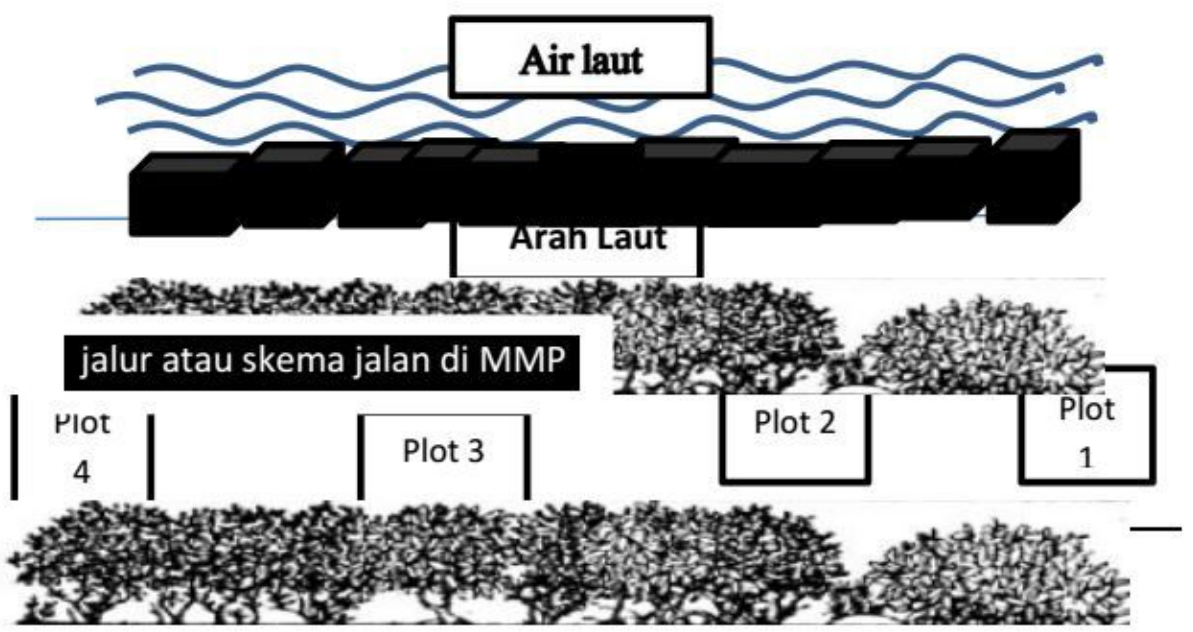

Gambar 2. Sketsa pengambilan data kepiting biola di ekosistem mangrove Desa Pasir Kabupaten Mempawah

ke dalam wadah (toples). Spesies yang telah ditemukan, diidentifikasi menggunakan buku Fiddler Crabs of the Word (Crene, 1975).

Identifikasi kepiting biola berdasarkan pada karakteristik umum yaitu dilihat pada warna capit dan karapas, bentuk karapas dan orbite. Data yang diperoleh di analisis, Analisa data meliputi keanekaragaman, keseragaman, dominansi dan kelimpahan. Data parameter yang di ambil meliputi data $\mathrm{pH}$ tanah, jenis fraksi substrat dan pasang surut.

\subsection{Analisis Data}

Penetuan jumlah jenis dan struktur komunitas kepiting biola di lakukan dengan menghitung nilai keanekaragaman, keseragaman dan dominansi dengan menggunakan indeks sebagai berikut :

a. Keanekaragaman

$H^{\prime}=-\sum_{i=0}^{S} p i \ln p i$

Keterangan :

$H^{\prime}$ : Indeks diversitas Shannom-Weiner

$p_{i}$ : Proporsi jumlah individu jenis ke-1

$\left(\frac{n_{i}}{N}\right)$

$S$ : Jumlah jenis

b. Keseragaman

$E=\frac{H^{\prime}}{\ln s}$

Keterangan :

$E$ : Indeks keseragaman
$H^{\prime}$ : Indeks keanekaragaman

$S$ : Jumlah spesies

c. Dominansi

$$
C=\sum\left(\frac{n_{i}}{N}\right)^{2}
$$

Keterangan :

$C$ : Indeks dominansi Simpson

$n_{i}$ : Jumlah individu jenis ke-I

$N$ : Jumlah total individu seluruh jenis yang ditemukan

\section{Hasil dan Pembahasan}

3.1 Jumlah jenis kepiting biola (Uca spp.)

Hasil penelitian yang telah dilakukan di kawasan ekosistem mangrove Desa Pasir, Kabupaten Mempawah, mendapatkan 3 spesies $U c a$ spp. yaitu $U$. forcipata, U. rosea dan $U$. dussuimeri. Penelitian Subprayogi et al., (2013) mengenai keanekaragaman kepiting biola (Uca spp.) di Desa Tungkal 1 Tanjung Jabung Barat juga mendapatkan 3 spesies yang sama, yaitu $U$. forcipata, $U$. rosea dan $U$. dusuimeiri. Menurut pratiwi (2007) Uca spp. berhabitat di daerah intertidal, terutama di sekitar hutan mangrove dan pantai berpasir. Uca spp. merupakan salah satu kepiting kecil semi-terestial yang memiliki peran penting dalam ekologi mangrove tropis.

Jenis kepiting biola paling banyak ditemukan pada plot 1, 2 dan 3 yang terdiri dari 3 spesies (Tabel 1). Hal ini diduga oleh vegetasi mangrove pada sekitaran plot tersebut relatif lebih dewasa sehingga 
Tabel 1. Jenis kepiting biola (Uca spp.) yang ditemukan di ekosistem mangrove Desa Pasir Kabupaten Mempawah Kalimatan Barat

\begin{tabular}{llcccc}
\hline \multirow{2}{*}{ No } & Jenis & \multicolumn{4}{c}{ Plot } \\
\cline { 3 - 6 } & & $\mathbf{1}$ & $\mathbf{2}$ & $\mathbf{3}$ & $\mathbf{4}$ \\
\hline 1 & Uca forcipata & + & + & + & + \\
2 & Uca rosea & + & + & + & - \\
3 & Uca dussumeiri & + & + & + & - \\
\hline & Jumlah & $\mathbf{3}$ & $\mathbf{3}$ & $\mathbf{3}$ & $\mathbf{1}$
\end{tabular}

$(+)$ : ditemukan/ ada ; (-) : tidak ditemukan/ tidak ada

memungkinkan untuk Uca spp. berkembang biak dengan baik. Vegetasi dewasa dapat menyediakan serasah (nutrisi) sebagai sumber makanan bagi kepiting biola. Soviana, (2014) menyatakan bahwa vegetasi mangrove yang cukup tinggi banyak menghasilkan serasah atau luruhan daun mangrove yang merupakan asupan terpenting bagi kehidupan kepiting. Weis, 2004 menambahkan bahwa makanan kepiting biola yaitu bakteri pengurai yang tumbuh pada sisa-sisa tumbuhan di antaranya yaitu bakteri, protozoa, alga dan diatom.

Kepiting biola paling sedikit ditemukan pada plot 4 (hanya satu spesies yang dijumpai yaitu $U$. forcipata) (Tabel. 1). Hal ini diduga plot 4 memiliki vegetasi mangrove yang masih kecil. Agustini (2014) mengatakan bahwa kerapatan jenis mangrove yang tinggi dapat menyusun suatu komunitas biota yang lebih komplek, begitu juga sebaliknya jika kerapatan jenis mangrove kecil tidak dapat menyusun suatu komunitas. Kondisi plot 4 yaitu memiliki vegetasi mangrove yang masih muda (kecil) (Tabel 1).

\subsubsection{Spesies Uca forcipata}

Secara umum U. forcipata memiliki warna yang sangat khas yaitu ungu muda (medium purple) dan merah kekuningan (red orange) pada bagian karapas dan capit. Karapas berbentuk seperti segitiga terbalik dan orbite tajam pada ujungnya.

Nontji (2005) menyatakan bahwa kepiting biola $U$. forcipata memiliki warna yang mencolok dan kontras dengan lumpur yang berwarna gelap. $U$. forcipata jantan memiliki capit dengan ukuran yang tidak sama besar (salah satu capit besar), sedangkan yang betina memiliki capit yang sama besar dan kecil. Warna betina umumnya agak gelap dibandingkan jantan (Crene, 1975). $U$. forcipata yang banyak ditemukan di ekosistem mangrove Desa Pasir Kabupaten Mempawah berwarna red orange (Gambar $3)$.

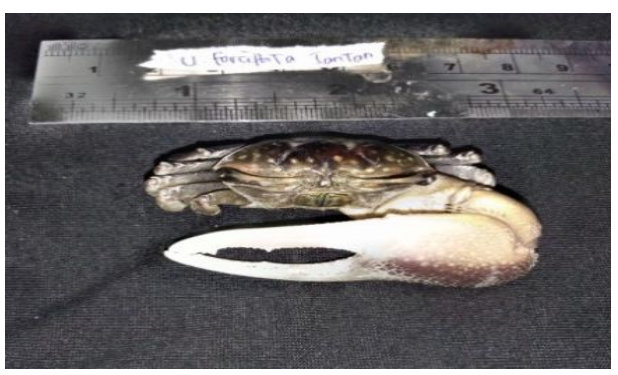

Gambar 3. Uca forcipata

\subsubsection{Spesies Uca dussumieri}

Spesies $U$. dussumieri paling sedikit ditemukan di ekosistem mangrove Desa Pasir Kabupaten Mempawah. U. dussumieri memiliki karapas yang berbentuk trapesium dan orbite yang melekuk tajam. Warna tubuh $U$. dussumieri umumnya adalah biru langit (sky blue) di capit dan karapas.

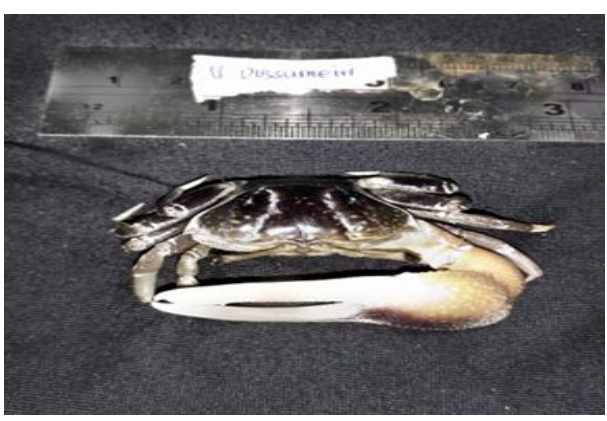

Gambar 4. Uca dussumieri

Crene (1975) menyatakan bahwa salah satu warna yang dimiliki oleh $U$. dussumieri adalah biru. $U$. dussumieri bersifat 
semi-terestrial yang aktif pada saat air surut dan masuk ke dalam lubangnya pada saat air pasang (Prianto, 2007)

\subsubsection{Spesies Uca rosea}

Warna $U$. rosea hampir sama dengan $U$. forcipata yaitu medium purple dan dark orange (oren tua). Bentuk karapas pada $U$. rosea jantan dan betina relatif sama. Identifikasi $U$. rosea mengacu pada daerah orbital dan lateral angel yang merupakan bagian dari karapas. Karapas jantan memiliki lebar mencapai $27,5 \mathrm{~mm}$, sedangkan betina mencapai $17,5 \mathrm{~mm}$. U. rosea berhabitat pada kawasan dengan kondisi substrat yang berlumpur dan dipenuhi vegetasi mangrove (Muniarti, 2010). U. rosea yang ditemukan warna yang sama yaitu oren tua (Gambar 5).

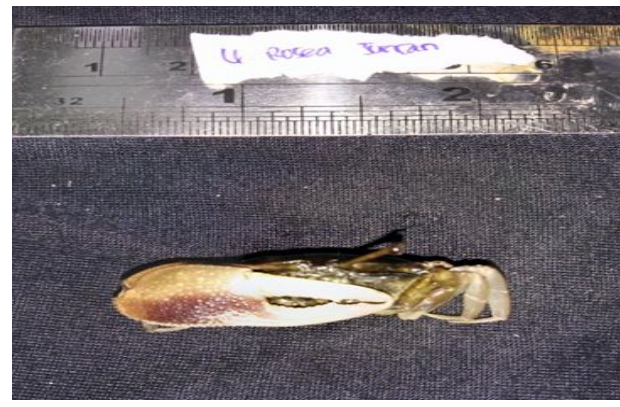

Gambar 5. Uca rosea

\subsection{Struktur Komonitas Kepiting Biola (Uca spp.) di ekosistem mangrove Desa Pasir Kabupaten Mempawah}

Komunitas kepiting biola (Uca spp.) di ekosistem mangrove Desa Pasir Kabupaten Mempawah memiliki nilai keanekaragaman yang berkisar antara 0 - 0,988 (Tabel 2) Nilai indeks tersebut menunjukan keanekaragaman kepiting biola di ekosistem mangrove Desa Pasir Kabupaten Mempawah tergolong rendah. Menurut Odum (1996) nilai indeks keanekaragaman 0-1 dikatakan rendah, 1-3 termasuk dalam kategori sedang dan nilai lebih dari 3 menunjukan tingginya keanekaragaman di suatu wilayah.

Indeks dominansi (C) komunitas kepiting biola yang berada di ekosistem mangrove Desa Pasir berkisar antara 0,430 - 1. Plot 4 memiliki nilai indeks dominansi tertinggi (1) yang digolongkan dalam kategori tinggi, sedangkan 3 plot lainnya tergolong sedang. Sesuai dengan pernyataan Odum (1996) bahwa batas nilai indeks dominansi berkisar antara 0-1. Indeks dominansi 1 menunjukan dominansi oleh satu jenis spesies sangat tinggi atau hanya terdapat satu jenis pada suatu komunitas, sedangkan nilai indeks mendekati 0 menunjukan bahwa diantara jenis spesies yang ditemukan tidak mendominansi.

Nilai indeks keseragaman (E) yang berada di ekosistem mangrove Desa Pasir berkisar antara $0-0,308$ tergolong dalam kategori rendah. Kreb (2014) mengatakan bahwa keseragaman dapat diperoleh dari hubungan diantara keanekaragaman ( $\left.\mathrm{H}^{\prime}\right)$ dengan nilai maksimal, yaitu dengan rumus indeks keseragaman.

Indeks keanekaragaman yang tergolong rendah dapat disebabkan oleh beberapa faktor di antaranya pertumbuhan vegetasi mangrove yang belum cukup dewasa sehingga tidak menghasilkan serasah yang cukup untuk nutrisi bagi Uca spp. Faktor pasang surut juga dapat mempengaruhi kehidupan $U c a$ spp. Jenis kepiting dari famili Ocypodidae aktif pada siang hari (diurnal) ketika air laut surut (Muniarti, 2010). Faktor lain yang mempengaruhi keanekaragaman Uca spp. yaitu polusi suara atau pun getaran yang disebabkan oleh aktivitas manusia dan alam karena Uca spp.

Tabel 2. Struktur komunitas kepiting biola (Uca spp.) yang berada di ekosistem mangrove Desa Pasir Kabupaten Mempawah

\begin{tabular}{ccccccc}
\hline & \multicolumn{6}{c}{ Indeks } \\
\cline { 2 - 7 } Plot & \multicolumn{2}{c}{$\mathrm{H}^{\prime}$} & \multicolumn{3}{c}{$\mathrm{C}$} & \multicolumn{2}{c}{$\mathrm{E}$} \\
\cline { 2 - 7 } & Nilai & Kategori & Nilai & Kategori & Nilai & Kategori \\
\hline 1 & 0,980 & $\mathrm{R}$ & 0,410 & $\mathrm{~S}$ & 0,308 & $\mathrm{R}$ \\
2 & 0,960 & $\mathrm{R}$ & 0,430 & $\mathrm{~S}$ & 0,288 & $\mathrm{R}$ \\
3 & 0,990 & $\mathrm{R}$ & 0,410 & $\mathrm{~S}$ & 0,297 & $\mathrm{R}$ \\
4 & 0 & $\mathrm{R}$ & 1 & $\mathrm{~T}$ & 0 & $\mathrm{R}$ \\
\hline
\end{tabular}

(H'): keanekaragaman, (C): Dominansi, (E) keseragaman, (R): Rendah, (T):Tinggi, (S): Sedang 
menyukai habitat yang tenang dan sepi. Chairunnisa (2004) mengatakan bahwa kepiting yang berada di ekosistem mangrove memiliki daya adaptasi yang tinggi terhadap perubahan lingkungan, namun akan menghindar jika kehidupannya terusik.

Rendahnya keanekaragaman dan keseragaman serta tingginya nilai dominansi diduga dipengaruhi oleh aktivitas manusia. Adanya kegiatan manusia seperti penebangan pohon dan aktivitas pejalan kaki juga dapat mengurangi kelimpahan kepiting, karena lingkungan akan mengalami suatu tekanan dan perubahan fisik (Pratiwi, 2014).

Keanekaragaman juga ditandai oleh kondisi subtstrat yang berada di lokasi penelitian. Lim (2005) menyatakan bahwa komposisi sedimen adalah faktor penting yang

\subsubsection{Pengukuran pasang surut}

mempengaruhi kelimpahan dan sebaran jenis Uca spp. dimana kepiting yang ditemui pada kondisi yang berlumpur berbeda dengan jenis kepiting yang hidup pada daerah yang berpasir. Muniarti, (2010) menyatakan bahwa jenis substrat berlumpur atau liat biasanya habitat untuk U. forcipata dan $U$. rosea, sedangkan substrat lempung berpasir habitat untuk $U$. dussuimeiri.

\subsection{Faktor Fisika Kimia Lingkungan \\ 3.3.1 Jenis Fraksi Substrat}

Jenis substrat merupakan faktor pembatas yang dapat mempengaruhi kehidupan dan penyebaran kepiting biola pada ekosistem mangrove. Jenis substrat yang mendukung kehidupan kepiting biola yaitu lumpur liat yang banyak mengandung pasir halus. Tipe substrat merupakan perbandingan relatif (\%) antara fraksi debu, liat dan berpasir. Fraksi lanau merupakan penyusun substrat terbesar di plot $1(49 \%)$ dan plot $4(49 \%)$. Fraksi lanau merupakan habitat untuk spesies $U$. forcipata dan U. rosea (Hamidah, 2014). Plot 2 memiliki persentase fraksi lempung dan lanau yang sama (47\%). Substrat pada plot 3 sebagian besar tersusun atas fraksi lempung (48\%) dan lanau (44\%). Substrat lempung dan bepasir biasanya digemari oleh U. dussuimeiri (Hamidah, 2014). Nybakken (1992) menyatakan bahwa substrat dasar merupakan salah satu faktor ekologi utama yang mempengaruhi skuktur komonitas makrozoobenthos, termasuk kepiting biola. Hal ini menunjukan kepiting biola dapat hidup baik pada kondisi substrat yang lanau.

\subsubsection{Nilai pH Tanah}

Karena fraksi lanau lebih banyak mengandung bahan organik sebagai nutrisi.

Pengaruh derajat keasaman $(\mathrm{pH})$ memiliki peran penting sebagai informasi dasar di suatu lingkungan perairan. Derajat keasaman yang tinggi mendukung keberadaan organisme pengurai untuk menguraikan bahan organik yang berada di lingkungan mangrove, sehingga tanah di lingkungan tersebut mempunyai tingkat keasaman yang tinggi. Hasil pengukuran $\mathrm{pH}$ tanah dalam penelitian ini adalah berkisar 6-6,4 Kisaran nilai yang diperoleh termasuk dalam kategori baik bagi pertumbuhan kepiting. Wahyuni dan Ismail, (1987) mengatakan bahwa jenis kepiting dapat hidup pada kondisi perairan yang asam yaitu $\mathrm{pH}$ rata-rata 6,5 serta daerah tersebut mengandung subsrat lumpur liat.

Pasang surut merupakan faktor lingkungan yang sangat mempengaruhi kehidupan biota, khususnya kepiting biola. Pengaruh pasang surut menunjukan adanya penggenangan air yang ada di dalam ekosistem mangrove, yang dapat berakibat secara langsung terhadap keberadaan dan kehidupan kepiting (Gita, 2015). Hasil pengukuran air pasang nencapai $1,50 \mathrm{~m}$, mulai pasang pada pukul 16.00 dan puncak pasang tinggi ketika malam hari (19.00). Keadaan ini mempengaruhi keberadaan kepiting dan daya adaptasi dari kepitingbiola. Plot 1, 2, 3 dan 4 memiliki letak yang sejaar garis pantai, sehingga memungkinkan jika pasang tinggi akan menggenangi semua area plot tersebut. Muniarti, (2010) menyatakan bahwa kepiting dari famili Ocypodidae aktif pada siang hari ketika air laut surut.

\section{Kesimpulan}

Kesimpulan dari penelitian ini adalah :

a. Kepiting biola (Uca spp.) yang ditemukan di ekosistem mangrove Desa Pasir Kabupaten Mempawah terdiri dari 3 spesies, yaitu Uca forcipata, Uca rosea dan Uca dussuimeri.

b. Komunitas kepiting biola (Uca spp.) yang berada di ekosistem Mangrove Desa Pasir Kabupaten Mempawah memiliki keanekaragaman dan keseragaman yang rendah, serta dominansi yang tinggi.

c. Faktor lingkungan yang mempengaruhi kehidupan kepiting biola yaitu $\mathrm{pH}$ tanah berkisar $6-6,4$ jenis substrat yang mendominansi adalah substrat lanau dan pasang surut. 


\section{Daftar Pustaka}

Chairunnisa, R. 2004. Kelimpahan Kepiting bakau (syclla spp.) di kawasan hutan mangrove KPH Batu Ampar. Kabupaten Pontianak. Kalimatan Barat. Skripsi. Program studi ilmu Kelautan. Bogor: Institut Pertanian Bogor.

Crane, J. 1975. Fiddeler Crabs of the worid. Princeton: Princeton University press.

Gita, R.S.D. 2015. Pengaruh factor Abiotik Terhadap Keanekaragaman dan Kelimpahan Kepiting Bakau (Scylla spp.) di Hutan Mangrove Blok Bedul taman Nasional Alas Purwo. Tesis. Jemeber: Universitas jember.

Hamidah, ---. 2014. Kepadatan kepiting biola (Uca spp.) jantan dan betina di Desa Tungkal 1 Tanjung jabung Barat. Riau: Universitas Riau.

Indriyanto. 2010. Ekologi hutan. Jakarta: Bumi Aksara.

Khairuddin, B. Yulianda, F. Kusmana, and C. Yonvitner. 2015. Status Keberlanjutan dan Strategi Pengelolaan Ekosistem Mangrove Kabupaten Mempawah, Provinsi Kalimantan Barat. Bogor: Institut Pertanian Bogor.

Kreb, J.C. 2014. Ecologycal methodology. 3nd edition. Weisey: Published. by addision.

Kustanti, A. 2011. Manajemen Hutan Mangrove. Bogor: IPB Press.

Lim S.L.L. 2005. Influence of biotope characteristics on the distribution of Uca annulipes (H. Milne Edwards, 1837) and U. vocans (Linnaeus, 1758) (Crustacea: Brachyura: Ocypodidae) on Pulau Hantu Besar. Singapore. The Raffles Bulletin of Zoologi 53(1):111-114

Muniarti, D.C. 2010. Keanekaragaman Uca spp. dari Segara-Anakan, Cilacap, Jawa Tengah Sebagai pemakan deposit. Fauna Indonesia. 9. 19-23.

Natania, T. 2017. Struktur komunitas kepiting biola (Uca spp.) di ekosistem mangrove Desa Kahpayu Pulau Enggano. Program studi ilmu kelautan dan perikanan. Bengkulu:---.

Nondji, A. 2005. Laut Nusantara. Jakarta: Djambatan.

Nybakken, J.W. 1992. Biologi Laut. Suatu Pendekatan Ekologis. Jakarta: Gramedia.

Odum, E.P. 1996. Dasar Dasar Ekologi. Edisi ke tiga. Yogyakarta: Universitas Gadjah Mada.

Pratiwi R. 2007. Jenis dan sebaran Uca spp. (Crustacea: Decapoda: Ocypodidae) di daerah mangrove delta mahakam. Kalimantan Timur. Jurnal Perikanan. 9(2). 322-328.

Pratiwi R. 2014. Sebaran kepiting mangrove (Crustacea: Decapoda) yang terdaftar di kleksi rujukan Pusat Penelitian Oseanografi. LIPI.

Prianto, E. 2007. Peran Kepiting Sebagai Spesies Kunci (Keystones Spesies) pada Ekosistem mangrove. Prosiding forum perairan umum
Indonesia $1 \mathrm{~V}$. Balai Riset Perikanan Perairan Umun. Banyuasin.

Soviana, W. 2004. Hubungan Kerapatan mangrove terhadap kelimpahan kepiting bakau di Teluk Buo. Kecamatan Bungus Teluk Kabung, Padang. Sumatra Barat. Bogor: Fakultas Perikanan dan ilmu Kelautan Institut Pertanian Bogor.

Suprayogi, D. 2013. Keanekaragaman Kepiting Biola (Uca spp.) di Desa Tungkal 1 Tanjung Jabung Barat. Fakultas Keguruan dan Ilmu Pendidikan. Universitas Jambi.

Wahyuni, I.S, dan W. Ismail. 1987. Beberapa catatan tentang (scylla sercata) di daerah muara dua. Segera. Anakan, Cilacap. Prosedding, ---.Semarang.

Weiss, J.S and P. Weiss. 2004. Behavior of four species of filder crab genus uca in. Southeast. Sulawesi. Indonesia. hydrobiologi. 523. 47-58. 